\title{
Growth and Yield Response of Peanut (Arachis hypogaea L.) to Cow Manure Dosage and Phosphorus Fertilizer on Ultisol
}

\author{
Listati Silitonga, Edhi Turmudi, Widodo \\ Department of Crop Production, Faculty of Agriculture, University of Bengkulu \\ WR Supratman St, Kandang Limun, Bengkulu 38371, Indonesia
}

\author{
ARTICLE INFO \\ Keywords: \\ peanut, \\ cow manure, \\ phosphorus fertilizer, \\ Ultisol \\ Article history: \\ Received: March 28, 2018 \\ Accepted: June 28, 2018 \\ *Corresponding author: \\ E-mail: widodo@unib.ac.id
}

\begin{abstract}
Peanut plant production has decreased almost every year, caused by several factors such as cultivation techniques, diseases, varieties, competition with other commodities and the increasingly narrow land area. One effort to improve the yield of peanuts by optimizing ultisol land for cultivation of plants. Ultisol soil is one of acid soils, high Al content, low organic matter content, and low cation exchange capacity. Provision of fertilizer is one effort made to maximize the use of ultisol land. This study aims to determine the optimal dose of cow manure and phosphorus fertilizer for peanut plants and to determine the dose of cow manure and the appropriate dose of phosphorus fertilizer for peanut plant. The design used in this experiment was Randomized Complete Block Design (RCBD) with two factors arranged factorially. The first factor was dosage of cow manure consisting of 4 treatment levels i.e. 0 ton $\mathrm{ha}^{-1}, 10$ ton ha ${ }^{-1}, 20$ ton ha ${ }^{-1}$ and 30 ton $\mathrm{ha}^{-1}$. The second factor is phosphorus fertilizer (SP-36) consisting of 3 levels i.e. $0 \mathrm{~kg} \mathrm{ha}^{-1}, 100 \mathrm{~kg} \mathrm{ha}^{-1}$ and 200 $\mathrm{kg} \mathrm{ha}^{-1}$. From these two factors, there were 12 treatment combinations each treatment was repeated 3 times, so that 36 experiments were obtained. The results showed that the dosage of cow manure did not significantly affect the growth and yield of peanut plants. The dosage of phosphorus fertilizer did not significantly affect all variables of observation except on seed weight. The combination of dosage of cow manure and phosphorus fertilizer has no significant effect on the growth and yield of peanut plant.
\end{abstract}

\section{INTRODUCTION}

Peanut (Arachis hypogaea L.) is one of the food commodities consumed by society. In Indonesia, this plant become one of the main food crops after rice, corn and soybeans. In general, farmers in Indonesia cultivate peanut crops on vacant land after main crops. As a high economic value commodity, it contains high nutritional food, especially protein and fat (Simanjuntak et al., 2014), having 25\% -30\% protein content, $40 \%-50 \%$ fat, $12 \%$ carbohydrate, and vitamin B1, placing peanuts in the case of nutritional fulfillment after soybean crop. Peanuts have an important role in meeting the needs of foodstuffs. Besides it consumed directly, in industrial area peanut is manufactured as margarine, cooking oil. or consumed directly (Suwardjono, 2004).

The need of peanuts in 2013 is 912.000 tons per year, while the ability to produce peanut production is only 786.868 tons per year with the average consumption per capita about $3.17 \mathrm{~kg}$ per year with a population of 248.459 million people. The rate of increase in new productivity reaches $1.88 \%$ per year and the average population of $1.55 \%$ per year (Ministry of Agriculture, 2013). According to the Central Statistics Agency (2016), the production of peanuts in 2011 was 691.289 tons, in 2012 the production reached 712.857 tons, in 2013 the production of peanuts was 701,680 tons, by 2014 the production of peanuts reached 638.896 tons, in 2015 peanut production decline to 605.449 tons.

Peanut productivity in Indonesia is relatively low compared to countries in the ASEAN region such as the Philippines and Vietnam, it is seen with the value of peanut productivity in Indonesia which only reached $1.352 \mathrm{~kg} \mathrm{ha}^{-1}$. According to Indria (2005), peanut productivity is influenced by several factors such as cultivation, fertilization, varieties, environment, irrigation and intensity of pests and

ISSN: 1410-3354 / e-ISSN:2615-7136

Cited this as: Silitonga, L., E. Turmudi, Widodo . 2018. Growth and yield response of peanut (Arachis hypogaea 1.) to cow manure dosage and phosphorus fertilizer on ultisol. Akta Agrosia 21(1):11-18. 
diseases. The production of national peanuts is not able to meet the domestic, thus making Indonesia as one of the importers of peanuts. To overcome these problems, the national peanut production must be improved. In order to meet the need for peanuts, the government continues to increase production through increased productivity of land unity, expansion of planting areas and through intensification (Pitojo, 2005).

Bengkulu province is generally dominated by Ultisol land area of 3.44 million ha. Ultisol soils have properties that can inhibit plant growth. Some common problems of Ultisol soils are high soil acidity (average $\mathrm{pH}<4.5$ ), high $\mathrm{Al}$ saturation, low nutrient content and low organic matter content (BPTP, 2014). Soil reactions or low soil $\mathrm{pH}$ cause the unavailability of nutrient elements in the soil causing plants to have nutrient deficiency so that the crop production is not optimal (Ispandi and Munip, 2005).

Soil productivity can be increased using technology that can improve soil properties. Some materials that can be used to improve the soil condition are through fertilization. In general peanuts can be cultivated on various soil types, but plat productivity is optimum in fertile land. To improve soil fertility, fertilization needs to be done either using organic or inorganic fertilizers. The use of organic fertilizers can supply the macro and micro nutrients, increase the soil organic matter content so that the soil is able to retain water and increase the activity of microorganisms in the soil and also affect the soil properties such as raising $\mathrm{pH}$ and increase the Cation Exchange Capacity.

Cow manure is one of the organic materials that can improve soil structure, increase soil organic matter and as a source of nitrogen and phosphorous substances that are very important for the growth and development of plants (Farizaldi, 2014). In additioan of its available in large quantities, cow manure has advantages over other manures that has high fiber content such as cellulose, this is evident from the results of measurement parameters $\mathrm{C} / \mathrm{N}$ ratio is high $>40$ and composted cow manure contains nutrients Nitrogen $(2.0 \%)$, Phosphorus $(1.5 \%)$ and Potassium (2.2\%) (Hartatik and Widowati, 2010). Cow manure has complete nutrient content however its availability is low, so it needs to be combined with inorganic fertilizer.

Inorganic fertilizers are widely used in increasing the production of peanuts, one of them is phosphorus fertilizer. Element $\mathrm{P}$ is absorbed in the form of water-soluble inorganic compounds such as nucleic acids and phytins. Phosphorus that is absorbed by plants in the form of inorganic ions quickly turns into organic phosphorus compounds. These phosphors are mobile or easily move between plant tissues. The optimal level of phosphorus in the plant at vegetative growth phase is $0.3 \%-0.5 \%$ of the plant dry weight (Suprapto, 2002). Phosphate element is very useful for plants, especially in terms of energy transfer, protein preparation, coenzyme, nucleic acid and metabolic compounds. Phosphate elements can be obtained from inorganic fertilizers such as SP-36 fertilizer and TSP fertilizer. Fertilizer SP-36 contains $\mathrm{P}_{2} \mathrm{O}_{5}$ as much as $36 \%$.

Phosphate fertilizer is useful to encourage early growth of roots, growth of flowers and seeds, increase the percentage of the formation of flowers into seeds, increase plant resistance to pest and disease attacks, and improve soil nutrient structure. Peanut plants require more phosphate than nitrogen. Organic material combined with inorganic fertilizer gives higher yield than if using only organic or inorganic fertilizers solely (Pasaribu, 2014). This study aims to determine the optimal dose of cow manure on every dose of phosphorus fertilizer for peanut plants.

\section{MATERIALS AND METHODS}

This research was conducted from January to April 2017 at the farm land of Kandang Limun Village, Muara Bangkahulu Subdistrict, Bengkulu City, with Ultisol soil type at altitude \pm 10 meters above sea level (asl). The design used in this experiment was a Completely Randomized Block Design (RCBD) with two treatment factors arranged factorial. The first factor is the dosage of cow manure (S) consisting of 4 treatment levels, namely cow manure 0 ton ha ${ }^{-1}$ (S0), 10 ton ha ${ }^{-1}$ (S1), 20 ton ha ( S2) and 30 ton $h^{-1}$ (S3). The second factor is phosphorus fertilizer (SP-36) consisting of 3 levels: phosphorous fertilizer (SP-36) $0 \mathrm{~kg}$ ha-1 (P1), phosphorus fertilizer (SP-36) $100 \mathrm{~kg}$ ha-1 (P2) and fertilizer phosphorus (SP-36) $200 \mathrm{~kg}$ ha-1 (P3). From these two factors, there were 12 treatment combinations each treatment was repeated 3 times, so that 36 experiments were obtained.

Land preparation begins by clearing land from weeds that grow around the study area. Then, the soil is processed manually using a hoe with a depth of 20 $\mathrm{cm}$. Subsequently, a plot of $2 \mathrm{~m} \times 2 \mathrm{~m}$ of 36 plots was prepared in accordance with the number of treatment combinations with the interval spacing of $50 \mathrm{~cm}$ treatment and the distance between replications 100 $\mathrm{cm}$. Application of cow manure is done one week after the cultivation of land by mixing the soil and cow manure thoroughly.

Soil analysis was conducted early before tillage and at the end of the study aimed to know the potential of the soil. Soil analysis was performed by taking samples on each treatment. Analysis done in this research to know the level of $\mathrm{P}, \mathrm{C}$-organic and soil $\mathrm{pH}$.

The study used peanut of Talam variety. The seed selection includes large seed size, uniform, clean, not wrinkled and there is no scar on the seed. Seeds were planted two weeks aftter land treatment by digging as deep as $3 \mathrm{~cm}$ from the ground surface 2 seeds per planting hole and given furadan $3 \mathrm{G}$. Plant spacing was of $40 \mathrm{~cm} \times 20 \mathrm{~cm}$ so that there were 50 plant populations per experimental unit.

Cow manure is applied one week before planting in accordance with the dosage of treatment. The fertilizer is spread in each plot and then mixed evenly using a hoe. Phosphorus fertilizer (SP-36) was 
added at the time of planting according to the treatment dose, while Nitrogen (Urea) and Potassium $(\mathrm{KCl})$ fertilizers were administered in accordance with recommended fertilizer dosage (urea $50 \mathrm{~kg} \mathrm{ha}^{-1}$ and $\mathrm{KCl} 50 \mathrm{~kg} \mathrm{ha}^{-1}$ ). Fertilization is done by making a run on the line of plants, then covered with soil.

Plants were watered manually using watering can at the beginning of peanut plant growth when needed. Thinning of plants is done when the plant is 2 weeks after planting (WAP), by removing a plant which was less than optimal growth and left the one grew better. Weeding was done manually by pull weeds that grow around the plant at 2 weeks after planting and the weeding was done depending on the state of weeds that grow around the land. Piling was done 2 times simultaneously with weeding. The first piling was done at 2 weeks after planting (WAP) by raising the soil from around the plant forming long bunds so that the soil becomes loose so that ginofor can penetrate the soil, the next piling done at age 7 weeks after planting. Pest control was performed using alfametrin 15 g. $1^{-1}$ and imidacloporid $25 \%$ applied at 4 and 7 weeks after planting.

Harvesting wass characterized by brownish yellow leaves, some deciduous leaves, hardened stems and pods full and hard contain, harvest is done when the plant is 90 days after planting was done by removing the entire plant.

Variables observed were plant height, number of leaves, number of branches, greenish leaves, leaf area, number of root nodules, weight of pod, number of pod, number of empty pod, plant fresh weight, plant dry weight, and weight of 100 seeds. The initial soil analysis data consist of $\mathrm{pH}, \mathrm{C}$-organic, $\mathrm{P}$ and rainfall data were also collected as the supporting data.

The observational data were analyzed statistically with analysis of variance (ANOVA) using $\mathrm{F}$ test at $5 \%$ level. When the $\mathrm{F}$ test was significant, then the orthogonal Polynomial test was applied to determine the appropriate regression model.

\section{RESULTS AND DISCUSSION}

\section{Research Overview.}

This experiment was conducted from January 5 , 2017 to April 29, 2017. The land used for this research in the form of terrestrial land with ultisol type of soil that has not been treated before. The initial soil analysis results showed that the soil $\mathrm{pH}$ was 4.0 (acid soil), C-Organic $1.54 \%$ (low), P 6.25 ppm (low). After cow manure and phosphorus were applied, the soil $\mathrm{pH}$ became 5.0 (acid), C-Organic $2.11 \%$ (low) and P levels 11.06 ppm (high).

During the experiment, peanut plant growth showed fairly normal condition. Peanut growing power reaches $90 \%$. Based on climatological data during the study, the monthly rainfall during the research was conducted in January $(172.1 \mathrm{~mm}$ with 10 rain days), February $(670.8 \mathrm{~mm}$ with 20 rainy days), March (291.3 mm with 8 rainy days) and April (482.7 $\mathrm{mm}$ with 17 rainy days). Average rainfall during the study in January to April ranged from $386.98 \mathrm{~mm} \mathrm{month}^{-1}$, so that the irrigation on peanut plant was only done at the beginning of planting and the rest was not irrigated on peanut plants because the soil was still damp due to sufficient rainfall to support plant growth. Peanuts grown during the study showed normal growth. By the time the plant is 4 WAP, about $80 \%$ of the peanut plant population begins to bloom. At the time of peanut plants aged 4 WAP, pests attack peanut plants such as grasshoppers pests, beetles and aphids that cause the peanut plant leaves perforated and rolled. Control of pest attack was done chemically by spraying the plant with insecticide Imidakloprid $25 \%$ and Alfametrin 15 g. $l^{-1}$. After spraying pest control using Alfametrin insecticide 15 g. $1^{-1}$ with a dose of $1 \mathrm{ml} .1^{-1}$ done, at week 7 still seen pest attack so do second spraying by insecticide insecticide Imidakloprid $25 \%$ with dose $1 \mathrm{ml}^{-1^{-1}}$ and Alfametrin 15 g. $1^{-1}$ with dose 0.5 g. $1^{-1}$. Weeds that grow on research plots include narrow-leaved weed species and broadleaf weeds. The weeds grow a lot around the plant and are controlled manually, so as not to disrupt the growth of peanut crops. Peanuts grown during the study showed normal growth. By the time the plant is $4 \mathrm{WAP}$, about $80 \%$ of the peanut plant population begins to bloom.

The number and size of the canopy affect the weight of the plant stalk, the more leaves and the higher the plant, the fresh weight of the shoot will be greater. The fresh weight of the shoot is also influenced by water harvesting by plants. Peanut plant growth looks normal, according to descriptions of varieties, peanut seed height between 34.23-51.00 $\mathrm{cm}$, leaf number 163.8-363,20 strands, branch number 4.60-8.40 branches, greenish leaves 128.2291.51 , leaf area $32.75-40.80 \mathrm{~cm}^{2}$ and number of root nodule 3.60 - 64.0, where some agronomic character of a plant is influenced by environment especially phenotypical character, but the expression of genes carrying certain characters can not be affected by the environment (Asnawi and Dwiwarni, 2000).

The leaf area ranges from $32.75 \mathrm{~cm}^{2}$ to $40.8 \mathrm{~cm}^{2}$ with an average of $36.91 \mathrm{~cm}^{2}$, while the number of leaves ranges from 163.8 to 363.2 . The leaf area of a plant depends on the number of leaves, there was a tendency if the number of leaves the more the greater the leaf area. According Ma'sumah (2002), leaves play a very important role for productivity a plant. The number and size of leaves was influenced by genotypes and environmental factors, such as soil, water, light and nutrients.

The number of pods per plant is the principal yield component for peanut crops. The number of pods obtained in the range of 21.02 fruit and 54.88 fruit, while the void obtained in the range of 30.92 fruit to 63.84 pieces with an average of 553.52 pieces. The number of pods formed was determined by the amount of gynophores capable of penetrating the soil and capable of forming pods. The weight of pods ranged from 80.34 gram to moderate to 199.10 gram was very large. According to Maesarah pod weights are categorized into very small pods (35-50 grams), small (51-65 grams), medium (65-105 grams), large 
(106-155 grams) and very large ( $>155$ grams) (Tabel 1$)$. Basuki (2000) that the provision of organic materials in providing nitrogen, potassium, calcium and the availability of phosphorus element that is easily soluble in the soil is needed peanut plants for the development of pods.

One of the factors that influence the growth and development of branch is nutrient. The absence of significant differences in each treatment is suspected because the nutrient $\mathrm{P}$ of phosphorous fertilizer is less effectively absorbed by the plant in the early phase of the vegetative phase. Based on Figure 1 it can be seen the increase of number of branches week 2 and week 4 of each treatment is equivalent but at week 6 , week 8 and week 10 there is a variation in the number of branches increase. In the treatment of S3P1 (30 ton ha ${ }^{-1}$ of cow manure and $0 \mathrm{~kg} \mathrm{ha}^{-1}$ phosphorus fertilizer), it showed an average branch number of 5.08 branches and the lowest number of branches was found in S0P3 treatment $\left(0\right.$ ton ha ${ }^{-1}$ cow manure and $200 \mathrm{~kg} \mathrm{ha}^{-1}$ phosphorus fertilizer) that amounted to 4.15 branches.

The number of peanut plant leaves increased from 2 weeks to 10 weeks. In the $2^{\text {nd }}$ and $4^{\text {th }}$ weeks the number of leaves is equal, while at week 6 , week 8 and week 10 the number of leaves increases. At week 10 , the highest number of leaves was seen in the S2P3 treatment (20 ton $\mathrm{ha}^{-1}$ SP-36 fertilizer and $200 \mathrm{~kg} \mathrm{ha}^{-1}$ phosphorus fertilizer) with the value of
292.1 strands, while the lowest was in the S0P3 treatment (without SP-36 and $100 \mathrm{~kg} \mathrm{ha}^{-1}$ phosphorus fertilizer) with a value of 253.1 leaf blade (Figure 2). At the growth of number of leaves on the treatment of 30 tons $\mathrm{ha}^{-1}$ SP-36 fertilizer and $100 \mathrm{~kg} \mathrm{ha}^{-1}$ phosphorus fertilizer has resulted in growth with the number of leaves on average of 164.2 leaves.

In this study, the results of variance analysis (Table 2), showed that the effect of cow manure and phosphorus fertilizer showed an unreal interaction for all growth variables and observed results. In the dosage of manure dose no significant effect on the growth and yield of peanut crop, while the dosage of phosphorus fertilizer only affected the weight of groundnut seeds.

\section{Effect of Dosage of Cow Manure and Phosphorus on Growth and Yield of Peanut}

The result of variance analysis (Tabel 2) showed that the combination of cow manure and phosphorus fertilizer has no significant effect on all observation variables. It is suspected that cow manure and phosphorus doses can provide the nutrients needed by peanut plants to carry out their vegetative and generative growth activities. Or in other words cow manure and phosphorus fertilizers do not affect each other. This is in accordance with the statement of Sutedjo and Kartasapoetra (2006) which states that

Table 1. Peanut plant growth and yield

\begin{tabular}{|c|c|c|c|c|c|c|}
\hline No & Variable & Maksimum & Minimum & Average & STD & $\mathrm{CV}(\%)$ \\
\hline 1 & Plant height $(\mathrm{cm})$ & 51.00 & 34.23 & 44.97 & 4.704 & 7.59 \\
\hline 2 & Number of leaves & 363.20 & 163.80 & 272.21 & 48.970 & 10.83 \\
\hline 3 & Number of branches & 8.40 & 4.60 & 16.27 & 0.843 & 12.06 \\
\hline 4 & Greenish leaves & 291.50 & 128.20 & 199.81 & 31.880 & 3.78 \\
\hline 5 & Leaf area $\left(\mathrm{cm}^{2}\right)$ & 3315.90 & 4341.70 & 3848.80 & 247.720 & 23.46 \\
\hline 6 & Number of root nodules & 64.00 & 3.60 & 23.76 & 13.840 & 55.86 \\
\hline 7 & Weights pods (g) & 199.10 & 80.34 & 141.67 & 29.510 & 12.68 \\
\hline 8 & Number of pods & 54.88 & 21.02 & 37.55 & 8.244 & 16.86 \\
\hline 9 & Number of empty pods & 63.84 & 30.92 & 53.52 & 6.893 & 42.44 \\
\hline 10 & The fresh weight of the plant $(\mathrm{g})$ & 31.80 & 13.00 & 23.11 & 4.694 & 18.13 \\
\hline 11 & The dry weight of the plant (g) & 21.20 & 3.80 & 9.03 & 3.766 & 17.05 \\
\hline 12 & The weight of the crop seeds ( $\mathrm{g}$ ) & 22.34 & 6.40 & 14.05 & 3.904 & 25.67 \\
\hline 13 & Weight of 100 seeds $(\mathrm{g})$ & 97.60 & 37.70 & 56.63 & 9.048 & 14.90 \\
\hline
\end{tabular}

Description: STD: Standard Deviation, CV: Coefficient of Variation

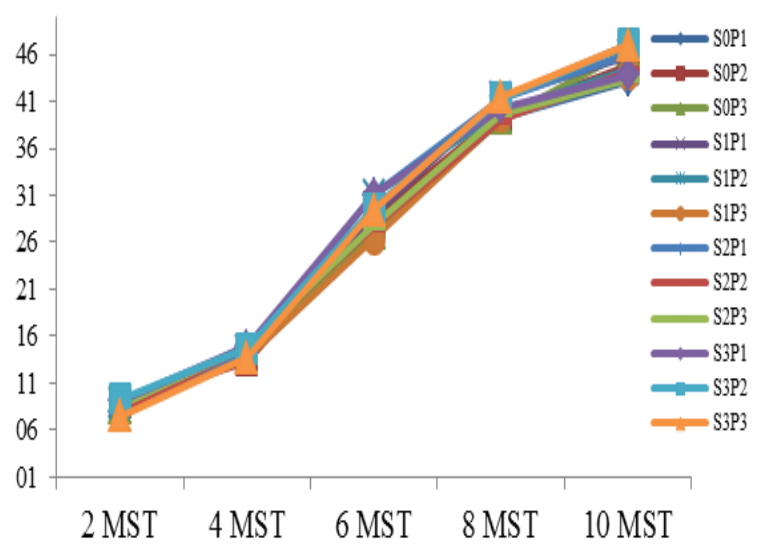

Figure 1. Plant height of peanut crop

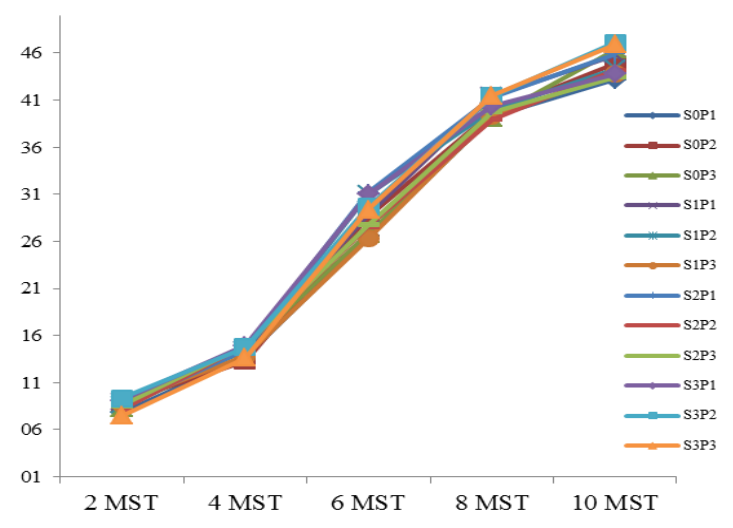




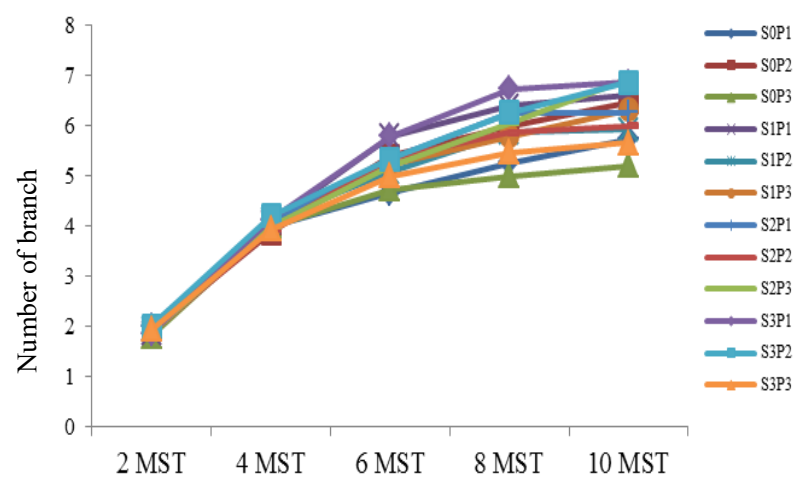

Figure 2. Graph of the number of branches of groundnut plants

if one factor is stronger than other factors so that other factors are covered and each factor has a farreaching nature and the nature of its work, it will produce an influential relationship in affect the growth of a plant.

The combination of both treatments does not always have a good effect on the plant. The combination of two treatments may encourage, inhibit, or in no way respond to the given treatment highly determined by growth factors and crop yields. The condition occurs because the response to the fertilizer given is determined by the genetic factors of the plant and climatic conditions. These factors are not independent but are related to one another. Suitable environmental conditions lead to optimal plant growth (Rizwan, 2010).

This study demonstrated that without the dosage of manure and phosphorus and with those treated with cow manure and phosphorus resulted in almost equal peanut growth and yield. This is due to both the treatment of cow manure and phosphorus fertilizer that causes normal crop conditions, although it has not provided a real interaction. This is in accordance with the statement of Sudarkoco (1992), which states that the provision of organic materials combined with inorganic fertilizers gives higher yields than when using only organic or inorganic fertilizers singly.

In this study normal peanut growth seen from plant height about $44.97 \mathrm{~cm}$, the number of pods and

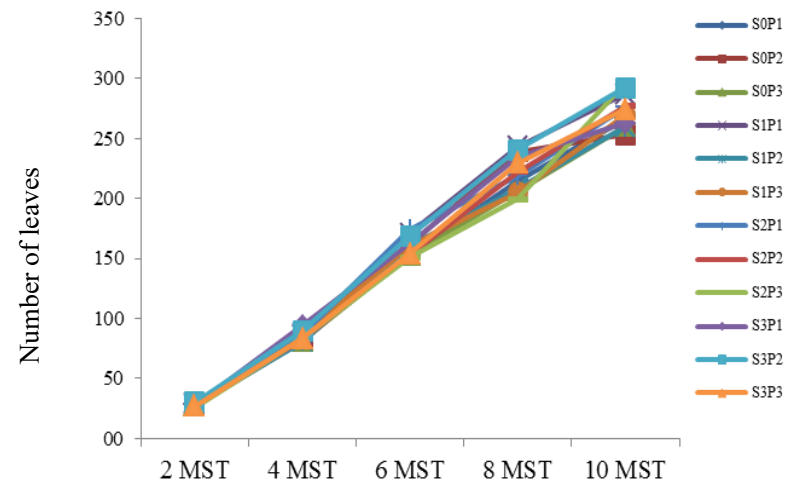

Figure 3. Graph of peanut plant leaf number

void pods about 23.1 pods and 8.7 pods and weight of 100 seeds 40.9 grams, it can be seen from the description of peanut varieties of talam. Asnawi and Dwiwarni (2000), stated that some of the agronomic properties of plants are influenced by the environment especially the phenotype properties, but the expression of genes that carry certain characters can not be influenced by the environment. Many of the least production of a plant is caused by environmental factors and genetic factors of each variety used. This is in accordance with the opinion of Allard (1992) which states that morphological or physiological properties are partially controlled by a single gene. According to Indria (2005), the maximum number and size of seeds is influenced by genetic factors and environmental conditions during planting experienced during seed filling.

On the other hand, the combination of dosage of cow manure and phosphor dose although it does not have a significant effect on peanut growth and yield but can improve the soil biological and chemical properties as seen in soil $\mathrm{pH}$ elevation, soil $\mathrm{P}$ content and C-organic increase soil. In this study showed that the treatment of 10 ton ha- 1 of cow manure and 100 $\mathrm{kg} \mathrm{ha}^{-1}$ of phosphorus fertilizer in comparison to other treatments could increase $\mathrm{pH} 5.2$, soil nutrient $\mathrm{P}$ content of $14.97 \mathrm{ppm}$ and its C-Organic content 2, $55 \%$. The interaction between cow manure and and phosphorus can improve aggregate and soil structure.

Table 2. The values of Analysis of Variance on observed variables.

\begin{tabular}{llccc}
\hline No & Variables & $\begin{array}{c}\text { Interaction Manure x } \\
\text { Phosphor }\end{array}$ & Cow Manure & $\begin{array}{c}\text { Phosphor } \\
\text { Fertilizer }\end{array}$ \\
\hline 1 & Plant height & $0.76 \mathrm{~ns}$ & $1.11 \mathrm{~ns}$ & $2.04 \mathrm{~ns}$ \\
2 & Number of leaves & $2.16 \mathrm{~ns}$ & $2.02 \mathrm{~ns}$ & $1.16 \mathrm{~ns}$ \\
3 & Number of branches & $0.79 \mathrm{~ns}$ & $0.44 \mathrm{~ns}$ & $1.01 \mathrm{~ns}$ \\
4 & Greenish leaves & $0.53 \mathrm{~ns}$ & $0.67 \mathrm{~ns}$ & $2.77 \mathrm{~ns}$ \\
5 & Leaf area & $1.15 \mathrm{~ns}$ & $1.65 \mathrm{~ns}$ & $2.07 \mathrm{~ns}$ \\
6 & Number of root nodules & $0.58 \mathrm{~ns}$ & $0.98 \mathrm{~ns}$ & $0.19 \mathrm{~ns}$ \\
7 & Weights pods & $0.19 \mathrm{~ns}$ & $1.66 \mathrm{~ns}$ & $0.53 \mathrm{~ns}$ \\
8 & Number of pods & $0.43 \mathrm{~ns}$ & $0.86 \mathrm{~ns}$ & $2.94 \mathrm{~ns}$ \\
9 & Number of empty pods & $0.46 \mathrm{~ns}$ & $1.91 \mathrm{~ns}$ & $1.23 \mathrm{~ns}$ \\
10 & The fresh weight of the plant & $0.20 \mathrm{~ns}$ & $0.26 \mathrm{~ns}$ & $2.41 \mathrm{~ns}$ \\
11 & The dry weight of the plant & $0.51 \mathrm{~ns}$ & $0.48 \mathrm{~ns}$ & $2.75 \mathrm{~ns}$ \\
12 & The weight of kernels per plant & $0.75 \mathrm{~ns}$ & $1.72 \mathrm{~ns}$ & $4.13 *$ \\
13 & Weight of 100 seeds & $0.68 \mathrm{~ns}$ & $0.37 \mathrm{~ns}$ & $3.19 \mathrm{~ns}$ \\
\hline
\end{tabular}

Notes: $*=$ significantly different on level $5 \%, \mathrm{~ns}=$ non significant 
Manure is proven to reduce soil acidity and increase nutrient availability.

\section{The Effect of Dosage of Cow Manure on Growth and Yield of Peanut}

The treatment of cow manure does not significantly increase the growth and yield of peanut crops. This research is in line with the results of Maesarah research (2016), which reported that the treatment of cow manure on the coast with a level of 10 tons $\mathrm{ha}^{-1}, 20$ tons ha ${ }^{-1}$ and 30 tons $\mathrm{ha}^{-1}$ has no significant effect on plant height, root dry weight, root dry weight, number of pods per plant, number of active plant root nodules peanuts. This is allegedly caused because the nutrient content contained in cow dung manure is not enough available, so that the nutrients provided by the fertilizer has not been absorbed perfectly to encourage the growth of plants. The cause of nutrients has not been able to encourage the growth of plants associated with the supply of nutrients by organic matter contained in cow dung manure at various doses used are relatively slowly available (Neltriana, 2015). Sutanto (2002), stated that the type of organic fertilizer treatment has no significant effect on most of the observed variables, possibly caused by the nutrients contained slowly available. The effect of giving organic fertilizers can even be felt for several years after administration.

Manure that is given into the soil will be decomposed by soil microorganisms, transformed into humus or soil organic matter. With the addition of humus this will increase the supply of food for the plants, play a role for the formation and maintain the structure of the soil, increasing the capacity of groundwater content, increased soil aeration (Hadisumitro, 2002). Giving cow manure is insignificant to the growth and yield of peanut. This is expected because at the time of application of cow manure occurs high rainfall, so that organic matter contained in the soil due to the application of cow manure does not appear to affect all variables of plants because water is enough available for peanut plants.

Application of cow manure can lower Al-dd and increase soil $\mathrm{pH}$. Cattle manure $25 \mathrm{Mg} \mathrm{ha}^{-1}$ can decrease Al-dd of land by $2.0 \mathrm{cmol} \mathrm{kg}^{-1}$. The decline of acid-soil Al-dd due to the application of manure is

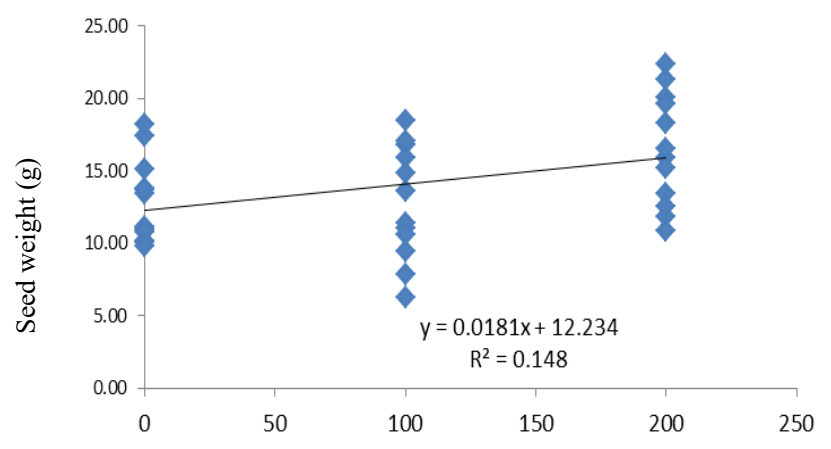

Dose of phosphorus fertilizer $\left(\mathrm{kg} \mathrm{ha}^{-1}\right)$ Figure 4. Relationship of dosing of phosphorus fertilizer to seed weight. related to the process of $\mathrm{Al}$ chelation in soil solution by organic acids. As is known the decomposition of organic matter will liberate organic acids such as citric acid, oxalate, malonate, tartrate, humic, fulvate and others (Muktamar et al., 1988).

\section{Effect of Phosphorus Fertilizer on Growth and Yield of Peanut Plant}

The results of variance analysis (Table 2), showed that the dosage of phosphorus fertilizer did not significantly affect all observation variables except on the observed variables of seed weight. Provision of phosphorus fertilizer with a dose of $0 \mathrm{~kg}$ $\mathrm{ha}^{-1}, 100 \mathrm{~kg} \mathrm{ha}^{-1}$ and $200 \mathrm{~kg} \mathrm{ha}^{-1}$ increase the weight of groundnut seeds. The dosage of phosphorus fertilizer on plant seed weight form a linear relationship with linear function equation $\mathrm{Y}=$ $0.0181 \mathrm{x}+12.234$. the value of the coefficient of determination $\left(\mathrm{R}^{2}\right)$ is 0.148 , it shows that only $14.8 \%$ of the total variability of the variable is not free $\mathrm{Y}$ is applied by the linear function of the independent variable specified. In other words $85.2 \%$ of $\mathrm{Y}$ diversity can not be explained by regression. The dosage of phosphorus fertilizer $200 \mathrm{~kg} \mathrm{ha}^{-1}$ is not the optimum dosage of peanut seed.

Figure 4, shows that increased dosage of phosphorus was accompanied by an increase in seed weight percentage. In the phosphorus dosage treatment, peanut plant response showed a linear increase in the weight of the seeds, so that increased phosphorus doses were still possible to obtain maximum results. According to Indria (2005), the maximum number and size of seeds is influenced by genetic factors and environmental conditions when planting during planting experienced on the filling of seeds. The condition of good planting land such as adequate water requirement of soil nutrients is sufficient then the maximum plant in the formation of seed filling so that the size of the seed will be larger and the weight of the seed will grow larger (Arifiana and Sjamsijah, 2017).

Phosphate element is very useful for plants especially in terms of energy transfer, protein preparation, coenzyme, nucleic acid and metabolic compounds to encourage early growth of roots, growth of flowers and seeds, increase the percentage of the formation of flowers into seeds. The formation of pods of contents depends on the soil moisture level and the supply of nutrients, especially phosphorus and calcium for the process of fertilization and seeding. The formation of pods required high moisture content for some time and enough nutrients, but too much water in the soil will also be able to disrupt the pod forming process.

The phosphorus fertilizer dosage treatment did not significantly affect the vegetative growth of peanut plant. This is assumed because with the dosage of phosphorus at the highest level of plant growth obtained remains the same. This is in accordance with the statement of Sumaryo and Suryono (2000) which states that the initial growth and medium growth parameters are less affected by SP-36 fertilizer, whereas in the final growth is 
significantly affected by SP-36 which is reflected in the weight of dry pods.

In the dosage of phosphorus fertilizer increases the level of nutrient $\mathrm{P}$ in the soil. However, due to soil $\mathrm{pH}$ which causes acidity of $\mathrm{P}$ soil content in the soil is not absorbed by the roots of the plant, because the acid soil found many elements of aluminum (Al) which in addition to poison plants also bind phosphorus elements. According to Hardjowigeno (2003) the factor that influences the availability of $\mathrm{P}$ for the most important crop is soil $\mathrm{pH}$. The phosphate is most easily absorbed by the plant at approximately neutral $\mathrm{pH}$ (6-7). According to Foth (1994) In the state of phosphorus deficiency, plant maturity and seed formation are usually delayed, resulting in many empty pods in groundnut plants

\section{CONCLUSIONS}

There was no difference in growth response and peanut yield on dosage of cow manure and phosphorus fertilizer dosage. Provision of phosphorus fertilizer with a dose of $0 \mathrm{~kg} \mathrm{ha}^{-1}$ to a dose of $200 \mathrm{~kg} \mathrm{ha}^{-1}$ can increase the weight of groundnut seeds. Cow manure and phosphorus fertilizer dosage can increase soil $\mathrm{pH}, \mathrm{P}$ and $\mathrm{C}$ Organic level of soil. Further research is needed on appropriate dosage of cow manure to maximize the growth and yield of peanut plant on ultisol.

\section{REFERENCES}

Allard, R.W. 1992. Pemuliaan Tanaman. Rineka Cipta. Jakarta. 336 hal.

Arifiana, N dan B. Sjamsijah.2017. F3 Plant Response Selection Of Soybean(Glycine max (L.) Merrill) Genotypes. Agriprima. 1(1): 50-58.

Asnawi, R dan I. Dwiwarni. 2000. Pengaruh Mulsa terhadap Pertumbuhan dan Produksi Enam Varietas Cabai (Capsium annum Linn.). Jurnal Tanah Tropika 5(1):5-8.

Badan Pusat Statistik. 2016. Produksi Kacang Tanah. https://www.bps.go.id/linkTableDinamis/view/ id/874 (Diakses 13 Oktober 2016).

Balai Pengkajian Teknologi Pertanian Bengkulu. 2014. Pemanfaatan Lahan Kering Masam Dengan Tumpangsari Jagung dan Kacang Tanah Di Provinsi Bengkulu. Balai Pengkajian Teknologi Pertanian Bengkulu. Bengkulu.

Basuki. 2000. Respon Tanaman Kacang Tanah (Arachis hypogaea L.)terhadap Cara Pengelolaan Tanah dan Pemberian Kompos Azolla. Skripsi. Fakultas Pertanian Universitas Brawijaya. Malang.

Farizaldi. 2014. Pengaruh Pemberian Pupuk Kandang Dan Abu Sabut Kelapa Terhadap Pertumbuhan Sentro (Centrosema pubescens) Pada Ultisol. Jurnal Penelitian Universitas Jambi Seri Sains. 16(1):71-76.

Foth, H. 1994. Dasar-dasar Ilmu Tanah. Erlangga. Jakarta.
Hadisumitro, L.M. 2002. Membuat Kompos. Penebar Swadaya. Jakarta.

Hardjowigeno, S. 2003. Ilmu Tanah. Mediyatama Sarana Perkasa. Jakarta.

Hartatik, W. dan L. R. Widowati. 2010. Pupuk Kandang. Balai Besar Penelitian dan Pengembangan Sumbrdaya Lahan Pertanian. Bogor

Indria, A.T. 2005. Pengaruh Sistem Pengolahan Tanah dan Pemberian Macam Bahan Organik Terhadap Pertumbuhan dan Hasil Kacang Tanah (Arachis hypogaeaL.). Skripsi. Universitas Sebelas Maret. Surakarta.

Ispandi, A dan A. Munip. 2005. Efektifitas Pengapuran terhadap Serapan Hara dan Produksi Beberapa Klon Ubikayu di Lahan Kering Masam. Jurnal Ilmu Pertanian 12(2):125 - 139.

Kementerian Pertanian. 2013. Prospek Pengembangan Agribisnis Kacang Tanah. Direktorat Budidaya Aneka Kacang dan Umbi. Jakarta.

Maesarah, M.M. 2016. Pengaruh Dosis Pupuk Kandang Ayam dan Sapi terhadap Pertumbuhan Gulma dan Hasil Kacang Tanah (Arachis hipogaea L.) di Lahan Pasir Pantai. http:// repository.upy.ac.id/12/1/ArtikelMeirina20\% Maesarah.pdf. (Diakses tanggal 14 Mei 2017).

Ma'sumah. 2002. Pengaruh Macam Media Tanam dan Konsentrasi Pupuk Organik Cair terhadap Pertumbuhan dan Hasil Buah Tanaman Tomat (Lycopersicum esculentum Mill.) secara Hidroponik. Skripsi. Fakultas Pertanian UNS Surakarta.

Muktamar, Z., D. Aneri dan Suprapto. 1998. Aplikasi Asam Sitrat dan Oksalat untuk Mengurangi Keracunan Aluminium pada Tanaman Kedelai. Jurnal Akta Agrosia. 2(1):22-27.

Neltriana, N. 2015. Pengaruh Dosis Pupuk Kandang Kotoran Sapi terhadap Pertumbuhan dan Hasil Ubi Jalar (Ipomea batatas L.). Skripsi. Fakultas Pertanian Universitas Andalas. Padang.

Pasaribu, P. K. 2014. Pertumbuhan dan Produksi Kacang Tanah (Arachis hypogaea L.) dengan Pemberian Pupuk Kandang Sapi dan Pupuk Fosfat. Jurnal Agroekoteknologi. 4(2):139-1395.

Pitojo, S. 2005. Benih Kacang Tanah. Kanisius. Yogyakarta.

Rizwan, M. 2010. Evaluasi Pupuk NPK dan pupuk organik terhadap Pertumbuhan dan Produksi Tanaman Kacang Tanah (Aachis hypogea L.) Ilmiah Abdi Ilmu. 3(2):422-430.

Siahaan, J. L. W. 2006. Pengaruh Dosis Fosfor terhadap Dua Anakan Pisang Ambon Curup Hasil Replanting. Skripsi. Budidaya Pertania. Fakultas Pertanian. Universitas Bengkulu. Bengkulu.

Simanjuntak, N. N. Sipayung dan Mariati. 2014. Tanggap Pertumbuhan dan Produksi Kacang Tanah (Arachis hypogaea L.) pada Dosis Pupuk 
Kalium dan Frekwensi Pembumbunan. Jurnal Online Agroekoteknologi 2(4):1396-1400.

Sudarkoco, S. 1992. Penggunaan Bahan Organik pada Usaha Budidaya Tanaman di Lahan Kering serta Pengelolaannya. Skripsi. Fakultas Pertanian IPB. Bogor.

Sutanto, R. 2002. Penerapan Pertanian Organik Permasyarakatan dan Pengembangannya. Kanisius. Yogyakarta.
Sumaryo dan Suryono. 2000. Pengaruh Dosis Pupuk Dolomit dan SP-36 terhadap Jumlah Bintil Akar dan Hasil Tanaman Kacang Tanah di Tanah Latosol. Agrosains 2(2):54-58.

Suwardjono. 2004. Pengaruh Beberapa Jenis Pupuk Kandang terhadap Pertumbuhan dan Produksi Kacang Tanah. http//www.ut.ac.id/jurnal/ suwardjono/pengaruh.htm. $\quad$ Di akses 12 September 2004. 